
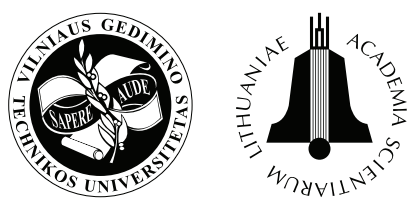

TRANSPORT

2010

25(1): 89-97

\title{
MULTI-CRITERIA DECISION MAKING SUPPORT TOOL FOR FREIGHT INTEGRATORS: SELECTING THE MOST SUSTAINABLE ALTERNATIVE
}

\author{
Győző Simongáti \\ Dept of Aircraft and Ships, Budapest University of Technology and Economics, \\ Stoczek u. 6, H-1111 Budapest, Hungary \\ E-mail: gysimongati@rht.bme.hu
}

Received 25 April 2009; accepted 1 February 2010

\begin{abstract}
Sustainable development has turned into a daily concept by now. Similarly, sustainable transport also appears increasingly often, primarily in transport policy and strategic plans. However, it would be equally important if we could apply this aspect for certain activities such as haulage and forwarding that are a part of transport. Today, forwarders select an optimal alternative concerning only the criteria related to the economic effectiveness of the transport task. In many cases, shippers are not aware neither of the concept of sustainable transport nor of harmful effects they generate. Hence, although there is a concept of 'freight integrator', only very few are able to meet the requirements laid down for it. No widespread method has been developed yet to compare transportation options. A similar situation can be faced discussing a traditional, purely economic approach and a theoretical modern aspect that would be in accordance with the principles of sustainable transport. The model that was developed at the Department of Aircraft and Ships of Budapest University of Technology and Economics was designed specifically to compare various options in terms of sustainability. The indicators as the elements of decision-making criteria applied in the model were derived from the indicators used for assessing the transport sector but modified according to the requirements of the decisionmaking task for a freight integrator. Finally, such sustainable performance index of certain alternatives is determined by two fundamentally different aggregation methods as 'fineness index'. This article presents the model structure and application using a concrete example.
\end{abstract}

Keywords: assessment of alternatives, freight integrator, multi-criteria decision making methods, sustainable development, sustainable transport.

\section{Introduction}

Sustainable development and the concept of sustainable transport can be found in a number of sources of literature (for example: Daly 1991; Pearce and Warford 1993; Our Common Future 1987; Towards Sustainable Transportation 1996; Transportation in Canada 2002; Jakimavičius and Burinskienè 2007, 2009a, 2009b; Rohács and Simongáti 2007; Burinskienè 2009; Kaklauskas et al. 2009; Mačiulis et al. 2009, etc.). Perhaps the most widely known and comprehensive definition was developed by Canadian Centre for Sustainable Transport in 1997 (Sustainable Transportation 2002) and adopted and further developed by the European Conference of the Ministers of Transport - 'A sustainable transport system is one that allows the basic access needs of individuals and societies to be met safely and in a manner consistent with human and ecosystem health, and with equity within and between generations; is affordable, operates efficiently, offers choice of transport mode, and supports a vibrant economy; limits emissions and waste within the planet's ability to absorb them, minimizes consumption of non-renewable resources, limits consumption of renewable resources to the sustainable yield level, reuses and recycles its components, and minimizes the use of land and the production of noise'.

In comparison with other definitions, this one clearly describes all important details of a very complex and multifaceted problem and accurately identifies individual and social interests, the limitations of activities, the aspects of sustainability over time and last but not least has been reviewed by political mechanisms and received general political acceptance.

This definition has been created for policy-makers and contains general guidelines that can be the basis for determining priorities along with developments that should be pursued at state or regional level. Becoming familiar with the concept of sustainability, 'how to live' guidelines on individuals or smaller communities also can be stated. These can help them in everyday activities to contribute to sustainable growth. This is particularly true for companies that act in the fields of greater eco- 
nomic importance like energy-production, building industry, transport etc. as well as for those that can choose between several solutions. A shipping company as a part of the transport system is a typical one.

At the same time, in the survey made in 2002 on behalf of the EU, the vast majority of shipping companies still did not think that way. The carried out analysis indicates that although a greater proportion $(70 \%)$ of logistics service providers include the concept of sustainability in their strategic objectives, only barely $40 \%$ of them carry out any kind of calculation or estimation, for example for social effects, and even fewer of those communicate with the clients (Bokor 2005). Moreover, only $10 \%$ of the clients are ready to pay any additional costs of environmentally friendly transportation, and hence, in practice, only market conditions dictate in the forwarders decision-making process.

Irrespectively of this, the term 'freight integrator' is already known and first appeared in 2001, in the White Paper which means it is a relatively new concept. According to (Study on Freight Integrators ... 2003), a freight integrator is a transport service provider arranging door-to-door shipment by the full usage of transport means and combining the modes of transport without prejudice in the most efficient and sustainable way. To simplify this, the freight integrator is such a forwarder who also takes into account the aspects of sustainability.

However, to accomplish the above described tasks, $\mathrm{s} /$ he would require an evaluation method that involves the principle of a sustainable transport system and assists in 'combining the modes of transport in the most efficient and sustainable way'; thus, the effects of the selected alternative outside economic interests can also be seen and communicated.

Today, for this purpose, there is no generally accepted evaluation system. Nevertheless, there are similar works only 'CREATING', an EU-funded research and development project of which are mentioned here, since our department has also taken part in it. The aim of the project was to examine cases where the modal shift from road to inland waterways had not only economic benefits but also was useful for other, for example environmental, safety and logistic areas (for details, see Rigo et al. 2007). Due to a different objective of this research, however, it did not examine specifically criteria for sustainable transport, and hence its evaluation system cannot be used without reservations for assessing the sustainability performance of the alternatives.

That was the main reason for developing a valuation and comparison model maximally adjusted to the decision-making tasks of the freight integrator using the above mentioned definition of sustainable transport. On the other hand, knowing that such a model was unable to change decisions on economic actors, there was another explicit goal for model development, namely to effectively assist all participants (including the governmental level) interested in sustainable transport to effectively communicate supporting the principles of sustainability a lack of which creates difficulties in envisaging necessary changes in thinking that is an essential element of sustainable development.

\section{Modelling}

Above all, a good and precise definition of sustainable transport is necessary for modelling giving a framework for the whole task. The already referred generally accepted definition was chosen. In the second step, the existing methods used to measure sustainability were examined. The results of research show that important and useful examples of sustainability assessment could only be found at the level of the transport sector the generally used indicator systems of which can be adapted for a 'sustainable' comparison of the alternatives. From numerous indicator-systems found in different sources of literature (including but not limited to Paving the Way for ... 2002; Definition and Vision ... 2002; Indicators for the ... 1999; Operationalising Sustainable ... 2004), 10 of those were examined in detail and the generally used (independently from the special aim of reports) indicators measuring the sustainability of the transport sector were selected (42 indicators remain).

To adapt some of these indicators for a companylevel, the determination of specific requirements was essential. These requirements significantly differ from the sector level due to the fact that modes specific multimodal transport chains rather than transport should be compared.

\subsection{Indicators}

Based on the previously filtered 42 sector-indicators and in accordance with requirements, a new indicator system containing 8 economic, 11 environmental and 4 social indicators has been developed. The method of calculating each indicator and the input data needed were specified and their sources were given based on a broad set of the existing literature. This indicator system is a basis for the calculation module of the evaluation model. Considering further calculations, all they were made applying an appropriate Microsoft Excel spreadsheet.

The indicators are grouped according to three main aspects of sustainability and summarized in Tables 1-3.

Some of the indicators (TP1, KFV1, KV2) are not included in the carried out assessment due to a lack of statistical or other relevant data or allocation methods for their calculations. However, it is very important to put them on the list thereby pointing to the need for collecting relevant data.

It is assumed that each alternative could be feasible within the framework (time-limit, fees etc.) of the customer and shipper's agreement. Therefore, the time required to display all goods is considered to be a criteria only when choosing not evaluating the alternatives. A version that is too slow for a client will not be selected for assessment (it is not a feasible alternative).

It is obvious, that the presented indicator system is only one of possible approaches evaluating the sustainability of the alternatives. However, we believe it is a consistent system that meets the definition of sustainable transport and the requirements of the freight integrator. 
Table 1. A list of economic indicator

\begin{tabular}{|c|c|c|}
\hline \multicolumn{3}{|c|}{ Economic indicators } \\
\hline Category & Name & Notation \\
\hline \multirow{4}{*}{ Costs } & Total cost & GK1 \\
\hline & Without infrastructure costs & GK11 \\
\hline & Infrastructure costs & GK12 \\
\hline & Loading-unloading costs & GK13 \\
\hline \multirow{3}{*}{$\begin{array}{l}\text { Reliability } \\
\text { of freighters }\end{array}$} & Existing relationships & GM1 \\
\hline & Accuracy & GM2 \\
\hline & Tracking \& tracing capabilities & GM3 \\
\hline \multirow{3}{*}{ Obstacles } & $\begin{array}{l}\text { A negative impact of the weather } \\
\text { on the route }\end{array}$ & GAK1 \\
\hline & $\begin{array}{l}\text { A negative impact of the weather } \\
\text { on the loading-unloading process }\end{array}$ & GAK2 \\
\hline & Traffic load, congestion & GAK3 \\
\hline Cargo safety & Risk of cargo damage & GA1 \\
\hline
\end{tabular}

Table 2. A list of environmental indicators

\begin{tabular}{|c|c|c|}
\hline \multicolumn{3}{|c|}{ Environmental indicators } \\
\hline Category & Name & Notation \\
\hline \multirow{3}{*}{$\begin{array}{l}\text { Natural } \\
\text { resource use }\end{array}$} & $\begin{array}{l}\text { Fossil energy use during } \\
\text { transportation }\end{array}$ & KEF1 \\
\hline & $\begin{array}{l}\text { Fossil energy use during loading- } \\
\text { unloading }\end{array}$ & KEF2 \\
\hline & $\begin{array}{l}\text { Rate of using renewable } \\
\text { resources }\end{array}$ & KEF3 \\
\hline $\begin{array}{l}\text { Energy } \\
\text { efficiency }\end{array}$ & $\begin{array}{l}\text { Energy efficiency of } \\
\text { transportation }\end{array}$ & KE1 \\
\hline Technology & $\begin{array}{l}\text { Level of technology involved } \\
\text { during vehicle construction }\end{array}$ & KT1 \\
\hline \multirow{4}{*}{$\begin{array}{l}\text { Emissions } \\
\text { to air }\end{array}$} & Total $\mathrm{CO}_{2}$ emissions & KLK1 \\
\hline & Total $\mathrm{NO}_{\mathrm{x}}$ emissions & KLK2 \\
\hline & Total PM emissions & KLK3 \\
\hline & Total $\mathrm{SO}_{2}$ emissions & KLK4 \\
\hline \multirow{2}{*}{$\begin{array}{l}\text { Emissions to } \\
\text { soil and water }\end{array}$} & Emissions to soil and water & KFV1 \\
\hline & Waste generation & KFV2 \\
\hline
\end{tabular}

Table 3. A list of social indicators

\begin{tabular}{cll}
\hline \multicolumn{3}{c}{ Social indicators } \\
\hline \multicolumn{1}{c}{ Category } & \multicolumn{1}{c}{ Name } & Notation \\
\hline Positive effect to society & State incomes & TP1 \\
\hline \multirow{3}{*}{ Negative effect to society } & Accident risk & TN1 \\
\cline { 2 - 3 } & Congestions & TN2 \\
\cline { 2 - 3 } & Noise emissions & TN3 \\
\hline
\end{tabular}

\subsection{Assessment Method}

The values of various indicators change in different scales and have different units in the model. To determine the 'goodness' of the alternatives according to the aspects of sustainability, i.e. when ranking alternatives, the values of very different kinds are to be summarized taking their weights in consideration. This is typically a multi-criteria decision task, and therefore it was necessary to examine whether the widespread methods could be applied for our special task and under what conditions. In case of a positive answer, the advantages and disadvantages of each of those should be established.

Concerning the above described situation, possible and applicable weighting and aggregation procedures were examined and identified. It was found that having in mind simple additive methods and fundamentally different outranking approaches (like PROMETHEE), the priorities of the freight integrator do not show substantial difference. However, in the provided outcomes, one can expect differences. For a general overview of multicriteria decision making methods, see e.g. Fülöp (2004); Brauers et al. (2008); Ginevičius et al. (2008); Morkvenas et al. (2008); Susnienè and Jurkauskas (2008); Šelih et al. (2008); Macek and Měštanová (2009); Maskeliūnaitė et al. (2009); Podvezko (2009); Turskis et al. (2009); Ulubeyli and Kazaz (2009); Podvezko and Podviezko (2010).

Therefore, two methods could be comparable as the model is designed so that ranking alternatives is done applying two methods (one additive and PROMETHEE) and the received results are displayed side by side. The model presents the sustainability 'goodness' of the alternatives using the 'Sustainability Performance Index'. Thus, the results of comparisons can be easily interpreted by both the freight integrator and the client.

To verify the reliability of the obtained results, the model uses the method of sensitivity/stability analysis offering a possibility of giving range for more than one parameter at the same time and for analyzing the impact of these uncertainties on the range of stability. The task is completed in a way that real relations between the established criteria are taken into account (for example: concerning the first criterion, there is +/-uncertainty about alternative $A$, but alternative $B$ could never be underestimated, so it has only + uncertainty). It should be noted that this is a unique possibility if compared to the existing commercial decision aiding software, like 'Decision Lab' or 'Expert Choice', the former uses PROMETHEE, the latter uses the AHP method.

\section{The Structure the Model}

On the basis of the foregoing, the model that has been set up for calculating the sustainability performance index of the alternatives has 3 main parts. The relation between them is shown in Fig. 1.

Work of the model and its modules in an Microsoft Excel spreadsheet environment. 


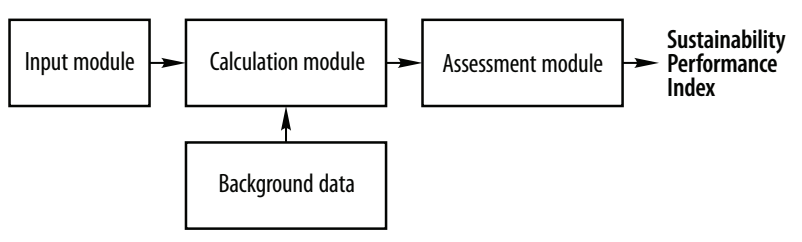

Fig. 1. The structure of the model

\subsection{Input and Calculation modules}

Following an accurate description of the task on transportation and the selection of feasible alternatives, the freight integrator should enter all input data. The basic data can be divided into several parts; in addition to general data, separate tables are used to input modespecific data for each part of the transport chain (such as inland waterway, road, rail sections, loading and unloading). The list of input parameters is based on the calculation methods and algorithms of indicators and has been compiled to include all information necessary for calculation but gives only a minimal amount of work to the freight integrator. The collected data could be displayed on one of the worksheets of the model.

By entering all necessary information, the evaluation of alternatives is done automatically on other sheets of the Microsoft Excel file including all other kinds (eg. statistical) of data that is not necessarily known by the freight integrator but essential for calculations.

\subsection{Assessment Module}

The basis of the undertaken assessment is the so-called decision table, in which the calculated values of the alternatives for each criterion can be found. To make assessment, the weights of the indicators are needed. The indicators are the criteria of decision making nomenclature.

\section{Weights}

The base-weights should firstly be determined and include the weights that are preferably determined by a group of experts taking into account the definition of sustainability. Hence, these are independent on the task that should be assessed and the model contains them as the fixed values, whereas the decision maker cannot modify them.

The most important principle of sustainability is that three dimensions (economic, environmental and social) should be equally followed. Therefore, three main areas must have strictly the same weight.

The weights for economic, environmental and social indicators were defined separately using the SMART method (Edwards 1977). The local (concerning the given aspect of sustainability) weights are determined using the method of normalisation. The so-called global weights of each indicator/criterion can be calculated from these concerning that three aspects have the same weights. The weights are summarised in Table 4 .

Weighing should be carried out by an expert group but the current state of the model reflects an individual perception of the author.

Edwards (1997) pointed to the importance of correcting weights according to the range of values. The aim
Table 4. Weights of indicators

\begin{tabular}{cccc}
\hline Notation & \multicolumn{3}{c}{ Weights } \\
\hline & SMART values & local & global \\
\hline GK1 & 420 & 0.750 & 0.250 \\
\hline GM1 & 25 & 0.045 & 0.015 \\
\hline GM2 & 30 & 0.054 & 0.018 \\
\hline GM3 & 15 & 0.027 & 0.009 \\
\hline GAK1 & 20 & 0.036 & 0.012 \\
\hline GAK2 & 10 & 0.018 & 0.006 \\
\hline GAK3 & 20 & 0.036 & 0.012 \\
\hline GA1 & 20 & 0.036 & 0.012 \\
\hline S & 560 & & \\
\hline KEF1 & 80 & 0.250 & 0.083 \\
\hline KEF2 & 10 & 0.031 & 0.010 \\
\hline KEF3 & 30 & 0.094 & 0.031 \\
\hline KE1 & 30 & 0,094 & 0.031 \\
\hline KT1 & 10 & 0.031 & 0.010 \\
\hline KLK1 & 40 & 0.125 & 0.042 \\
\hline KLK2 & 40 & 0.125 & 0.042 \\
\hline KLK3 & 40 & 0.125 & 0.042 \\
\hline KLK4 & 40 & 0.125 & 0.042 \\
\hline S & 320 & & \\
\hline TN1 & 40 & 0.333 & 0.111 \\
\hline TN2 & 40 & 0.333 & 0.111 \\
\hline TN3 & 40 & 0.333 & 0.111 \\
\hline S & 120 & & 1.000 \\
\hline & & &
\end{tabular}

of correction is that the weight of a criterion should be reduced in those cases where the alternatives are very similar or even totally the same. This task, however, can be carried out only after the conducted evaluation of various alternatives. In order to reduce the tasks of the freight integrator, since it is mathematically possible, correcting the weights should be 'automated' applying an appropriate algorithm. The multiplication of the correction factors and base-weights give the corrected weights. The sum of those, however, will not be equal to 1 , so normalization is repeatedly required.

\section{Aggregation with SAW}

Using the SAW method (Churchman et al. 1957), the values of various alternatives should be normalized. The process of normalization in the model takes place in the following way:

- if a greater value is better:

$$
a_{i j}^{\prime}=\frac{a_{i j}-a_{i j}^{\min }}{a_{i j} \max -a_{i j}^{\min }} ; i=1, \ldots, m ; j=1, \ldots, n \text {; }
$$

- if a smaller value is better:

$$
a_{i j}^{\prime}=\frac{a_{i j}^{\max }-a_{i j}}{a_{i j}^{\max }-a_{i j}^{\min }} ; i=1, \ldots, m ; j=1, \ldots, n .
$$

Applying this method, all values will be between 0 and 1 in the way that the better ones are closer to 1 .

Using the base equation of SAW (which is the weighted sum), the Sustainability Performance Index is as follows: 


$$
S P I_{j}=100 \cdot \sum_{i=1}^{m} w_{i}^{\prime} \cdot a_{i j}^{\prime} ; i=1, \ldots, m ; j=1, \ldots, n,
$$

where: $S P I_{j}$ is the Sustainability Performance Index of $A(j) ; w_{i}$ is corrected and normalized weight for criterion $C i$; $a_{i j}^{\prime}$ is the normalized value of $A(j)$ for criterion $C i$.

For a more detailed comparison, economic, environmental and social sub-indexes could also be defined in the following way:

$$
\operatorname{SPI}_{j}^{\text {eco }}=100 \cdot \sum_{i=1}^{m} w_{i}^{\prime} \cdot a_{i \text { eco } j}^{\prime} ; i=1, \ldots, m,
$$

where: $S P I^{e c o}{ }_{j}$ is the economic sub-index of alternative $j ; w_{i}{ }^{\prime}$ is corrected and normalized weight for criterion $C i$; $a_{i j}{ }^{e c o}$ is the normalized value of $A(j)$ for economical criterion $\mathrm{Ci}$.

Environmental and social sub-indexes are similarly defined. The results of the model are shown in the diagram (Fig. 2).

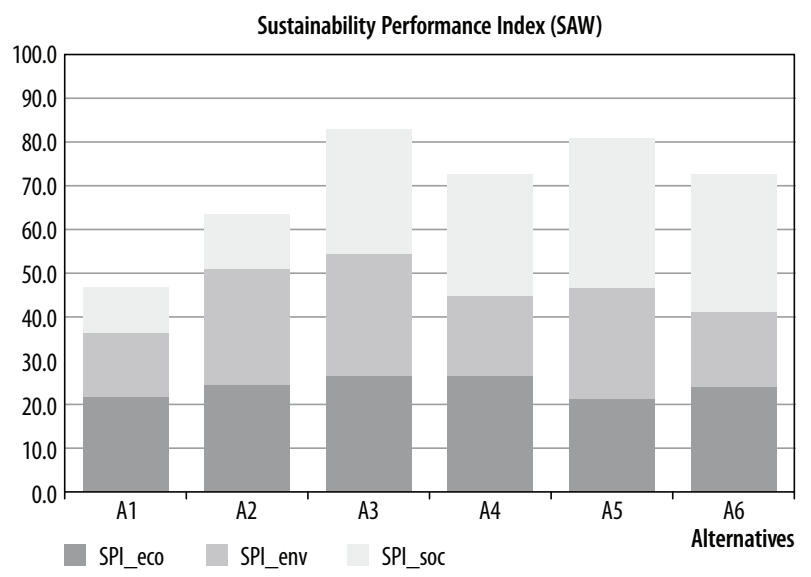

Fig. 2. Results by SAW

\section{Aggregation with PROMETHEE}

The applied method follows that written in (Brans and Vincke 1985). For all criteria, the trapezoidal preference function was used. Where the range of the alternatives is unknown, the threshold values are $q=3 \%$ and $p=75 \%$, whereas in case of GM1 and GM2, these are 0 and 1 respectively.

The Sustainability Performance Index applying this method is defined as the net outranking flow of the alternative:

$$
S P I_{j}=\Phi\left(A_{j}\right) \text {. }
$$

Mathematically, it is possible to decompose this according to three main aspects of sustainability. Apart from the description of the steps, SPI of the alternative can be written in the following form:

$$
S P I_{j}=\Phi\left(A_{j}\right)=\Phi\left(A_{j}\right)_{e c o}+\Phi\left(A_{j}\right)_{e n v}+\Phi\left(A_{j}\right)_{s o c} .
$$

A sample of the assessment results by PROMETHEE is presented in Fig. 3.

\section{Sensitivity/robustness analysis}

As mentioned above, robustness analysis should be carried out by both the alternative values and weights.

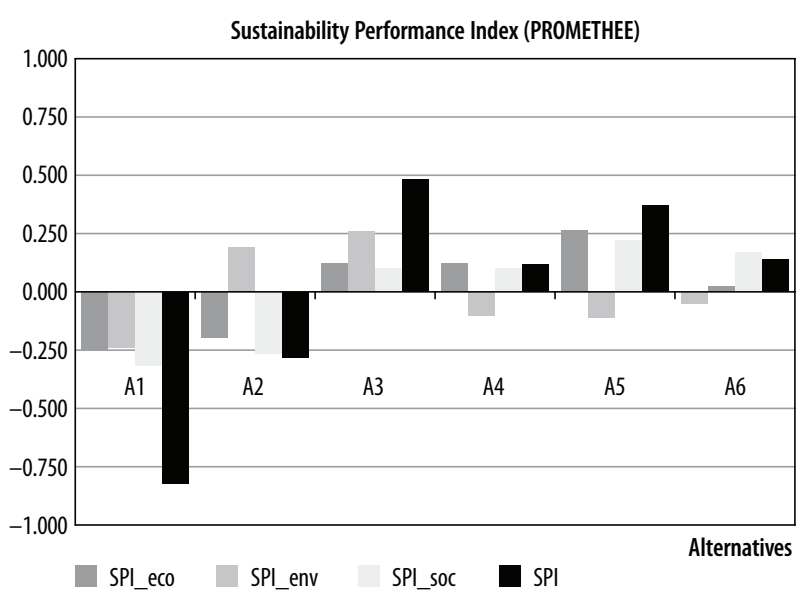

Fig. 3. Results by PROMETHEE

To this end, the weight for each indicator can vary in a wide range by using a scroll bar in the model. Changing the weight of an indicator, the others are automatically adjusted so that the amount of the weights in a group provides 1 . Moving the scroll bar, SPI values are immediately converted, and therefore it is very easy to visually check the impact of the weight on ranking the alternatives. Certainly, it is possible to simultaneously change more than one weight.

Due to uncertainty in the values of the alternatives, robustness analysis is quite similar. First, those alternatives should be identified the values of which are uncertain of some criteria. Also, the criteria and direction of uncertainty should be specified. Consequently, the established values could be changed by another scroll bar once again. Changing the values till rank reversal occurs, a stability interval can be determined and over again, more values can be varied at the same time.

The above introduced method helps with examining the true relationship between the uncertainties of the values.

\section{A case study on the Application of the Model}

\subsection{Conditions, Input and Calculated Data}

The basis for the case study is container liner services between Budapest and Constanza operated for a short period by the Hungarian Shipping Company. The alternatives are as follows:

- A1 - road haulage with modern EURO 3 class trucks, route on Fig. 4;

- A2 - transport on the Danube using a self-propelled ship plus a barge in convoy, capacity is 2.150 TEU;

- A3 - transport on the Danube by using an old push-boat with two pushed barges, capacity is 2.150 TEU;

- A4 - rail transport, electric traction, border crossing at Lökösháza, 3 TEU/railcar and 25 railcar/assembly.

A total amount of cargo is 300 TEU.

All input data is not presented here due to a lack of space. It should be noticed that costs are not calculated 


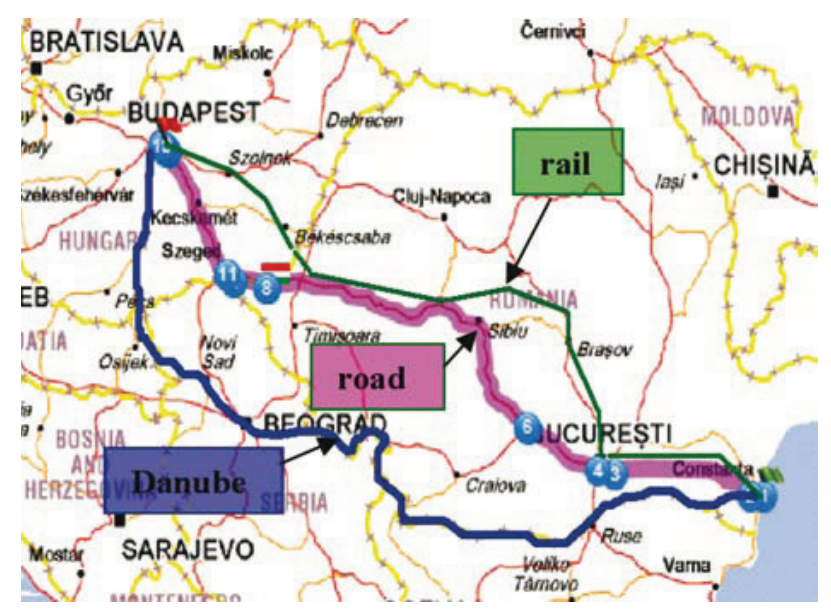

Fig. 4. Routes

as the quoted freight rates received from Hungarian intermodal service providers were used. The values of road and rail are 1050 and 1000 EUR respectively for one way and one 40' container. For the first approximation, a fee for inland waterway transport is 900 EUR including a 40 ' container (analysis will follow).

The example shows there is no intermediate transhipment and all alternatives from the Port of Constanza to Csepel Freeport, Budapest are examined. An important point is that empty running is not considered.

The values of the alternatives shown in the table below are calculated on the basis of the input data. The weights are identical to the previously stated global values. The last column in the table indicates the corrected weights due to the range of the alternative values (Table 5).

\subsection{Assessment}

The results given by the model can be seen in Fig. 5 .

Robustness analysis was done using both the weights and certain values of the alternatives. The obtained results are summarized in the Table 6 (rank reversal was searched between a worse alternative for inland waterway (IWW) and rail transport).

Table 6. Robustness analysis using the weights of a certain criterion

\begin{tabular}{ccc}
\hline & \multicolumn{2}{c}{ Range of stability } \\
\hline & SAW & PROMETHEE \\
\hline GK1 (separate) & above 4\% & above 18\% \\
\hline KEF1 (separate) & below 76\% & below 72\% \\
\hline GK1 and KEF1 & GK1: above 45\% & GK1: above 50\% \\
modified together & KEF1: below 55\% & KEF1: below 50\% \\
\hline
\end{tabular}

For example: if the weights are varied one by one, and the weight of GK1 is above $4 \%$, the ranks of the alternatives assessed by SAW are stable. For PROMETHEE, if the weight of GK1 is below $18 \%$, rank reversal occurs. If the weights of GK1 and KEF1 are changed si-

Table 5. The weights and results of the alternative values

\begin{tabular}{|c|c|c|c|c|c|c|c|}
\hline & \multirow[t]{2}{*}{ A 1} & \multirow[t]{2}{*}{ A 2} & \multirow[t]{2}{*}{ A 3} & \multirow[t]{2}{*}{ A 4} & \multirow[t]{2}{*}{ Dim. } & \multicolumn{2}{|c|}{ Weight } \\
\hline & & & & & & Corr. & c. $n$. \\
\hline GK1 & 157500 & 135000 & 135000 & 150000 & EUR & 0.250 & 0.257 \\
\hline GM1 & 5.00 & 4.00 & 4.00 & 5.00 & point & 0.015 & 0.015 \\
\hline GM2 & 9.00 & 9.00 & 9.00 & 7.50 & point & 0.018 & 0.018 \\
\hline GM3 & 66.7 & 0.0 & 100.0 & 75.0 & $\%$ & 0.009 & 0.009 \\
\hline GAK1 & 0.00 & 0.00 & 0.00 & 0.00 & $\%$ & 0.000 & 0.000 \\
\hline GAK2 & 0.00 & 0.00 & 0.00 & 0,00 & $\%$ & 0.000 & 0.000 \\
\hline GAK3 & 19.23 & 0.00 & 0.00 & 2.85 & $\%$ & 0.012 & 0.012 \\
\hline GA1 & 62.69 & 89.87 & 95.37 & 81.89 & $\mathrm{dn}$ & 0.012 & 0.012 \\
\hline KEF1 & 1698606 & 1792609 & 2293591 & 1863669 & MJ & 0.083 & 0.086 \\
\hline KEF2 & 0 & 0 & 0 & 0 & MJ & 0.000 & 0.000 \\
\hline KEF3 & 0 & 0 & 0 & 2.7 & $\%$ & 0.031 & 0.032 \\
\hline KE1 & 2.388 & 3.046 & 2.381 & 2.201 & $\mathrm{tkm} / \mathrm{MJ}$ & 0.031 & 0.032 \\
\hline KT1 & 4 & 4 & 33 & 18 & year & 0.010 & 0.011 \\
\hline KLK1 & 166.85 & 146.86 & 187.07 & 249.35 & $\mathrm{tCO}_{2}$ & 0.042 & 0.043 \\
\hline KLK2 & 2514.88 & 180.06 & 2777.93 & 640.51 & $\operatorname{kg} \mathrm{NO}_{\mathrm{x}}$ & 0.042 & 0.043 \\
\hline KLK3 & 58.62 & 19.23 & 141.32 & 77.73 & kg PM & 0.042 & 0.043 \\
\hline KLK4 & 380.51 & 119.57 & 318.12 & 1379.11 & $\mathrm{~kg} \mathrm{SO}{ }_{2}$ & 0.042 & 0.043 \\
\hline TN1 & 0.09915 & 0.00000 & 0.00000 & 0.00000 & $\mathrm{dn}$ & 0.111 & 0.114 \\
\hline TN2 & 93720 & 0 & 0 & 0 & EUR & 0.111 & 0.114 \\
\hline \multirow[t]{2}{*}{ TN3 } & 40835 & 0 & 0 & 5017 & EUR & 0.111 & 0.114 \\
\hline & & & & & & 0.972 & 1.000 \\
\hline
\end{tabular}



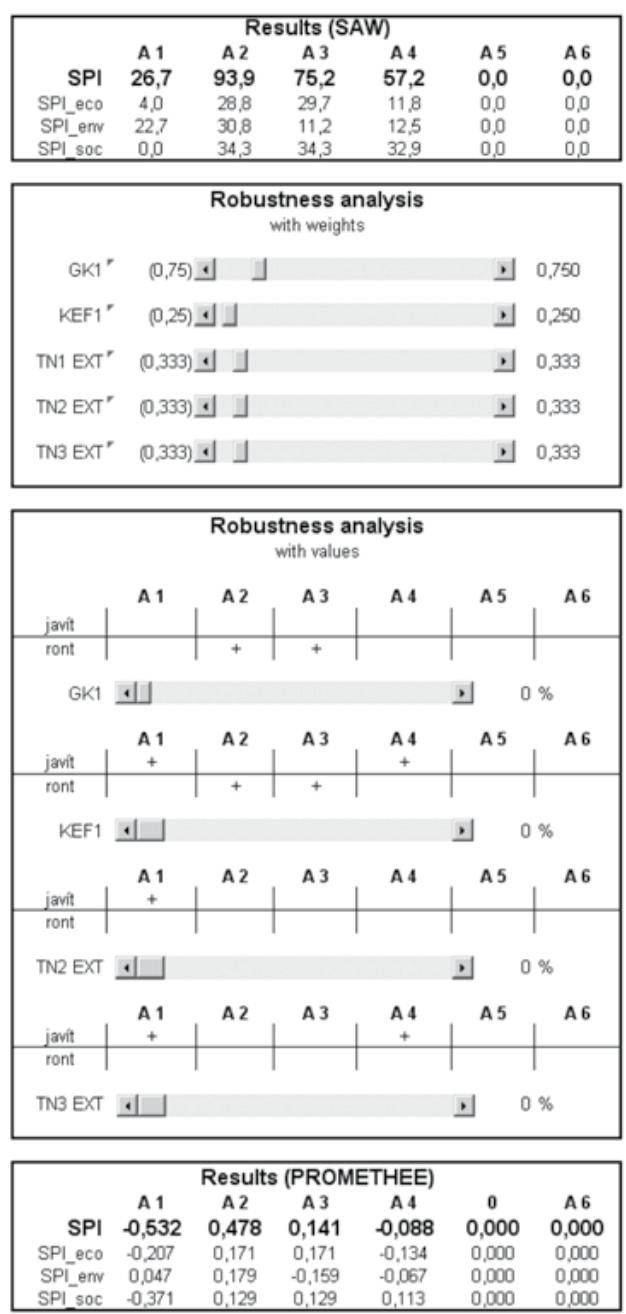
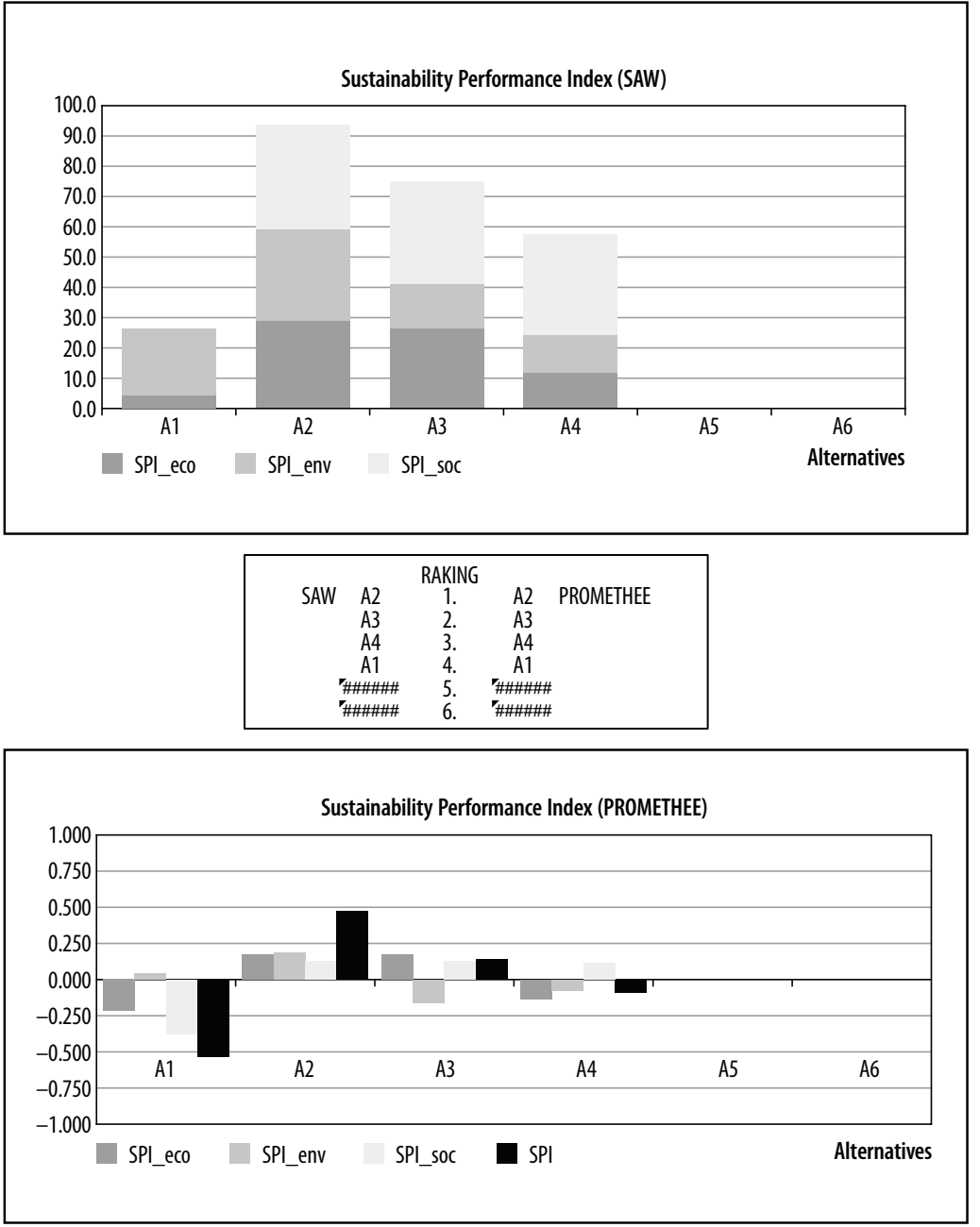

Fig. 5. Results of the case study on the container

multaneously, the results are stable if the weight of GK1 is above $45 \%$ and the weight of KEF1 is below $55 \%$.

Hence, it could be stated that the results are stable in the practical range of the weights of the selected indicators.

Prior to robustness analysis of the values, the following assumptions are made:

- only the values of GK1, KEF1, TN2 and TN3 are uncertain;

- in case of GK1 (costs), only the fees of alternatives A2 and A3 can be changed. The aim of analysis is exactly to find out the price that can be allowed to keep the first place for these two alternatives;

- having obtained the results of the first approximation, rank reversal can only occur if the KEF1 (energy consumption) values of A1 and A4 decrease and the values of A2 and A3 increase;

- since changes in TN2 values (congestion) of IWW and rail alternatives are not expected, only the value of A1 should be positively changed for rank reversal;

- concerning noise, only A1 and A4 can be improved.
The results of the conducted analysis are shown in Table 7. Sign '-' means that no rank reversal occurs. The numbers show difference allowed in terms of each indicator. For example, 62-66\% decrease in A1 and A4 and the same increase in A2 and A3 causes rank reversal. Varying the values of all 4 indicators simultaneously allows $9-10 \%$ changes until rank reversal takes place.

Table 7. Robustness analysis by the selected values

\begin{tabular}{ccc}
\hline & SAW & PROMETHEE \\
\hline GK1 (separate) & $10 \%$ & $9 \%$ \\
\hline KEF1 (separate) & $62 \%$ & $66 \%$ \\
\hline TN2 (separate) & - & - \\
\hline TN3 (separate) & - & - \\
\hline $\begin{array}{l}\text { GK1, KEF1, TN2 and TN3 } \\
\text { modified together, equally }\end{array}$ & $10 \%$ & $9 \%$ \\
\hline
\end{tabular}

The tables show that although they use different approaches, two methods give practically the same results.

Such kind of analysis is good not only for examin- 
ing the robustness of the results but also for answering the questions like:

- what is the maximum allowed price for IWW transport to keep it in the first place;

- concerning the fixed freight rates, how much energy consumption should be allowed for IWW transport to keep it as the most sustainable alternatives;

- how SPIs change if the number of transported TEUs and capacity usage decrease;

- etc.

Let's check the first question. Besides a different amount of uncertainty in the values of KEF1, Figure 6 shows what the maximum fee of alternatives A2 and A3 before rank reversal can be. The figure suggests that assuming $20 \%$ of uncertainty in KEF1, the Sustainability Performance Index of A4 and A3 will be equal if the pro container price is 970 and 962 EUR, by SAW and PROMETHEE respectively. If IWW is cheaper, A3 is better than the rail alternative (A4) or greater uncertainty can be allowed. Concerning a better 'naval' alternative, A2, the price could even be higher and make about 1014 EUR.

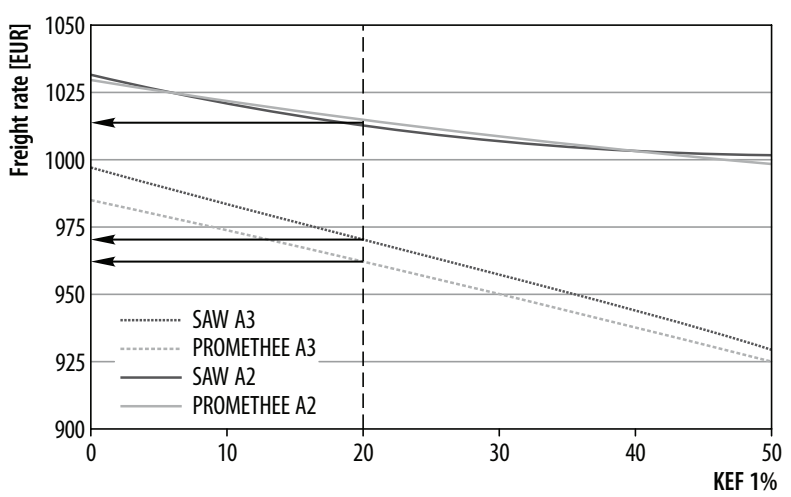

Fig. 6. Maximum allowed freight rate for IWW transport concerning equal SPIs

For alternative A3, two different methods give slightly different results but this is less than $1 \%$ in the freight rate, so it is negligible. Again, it can be stated that the methods give quite similar results.

Using the model, the other two questions can be easily answered.

\section{Summary}

The presented model certainly provides a good opportunity for further analysis. The carried out tests and analysis have revealed the versatile utility of the model and highlighted that multi-criteria decision aiding methods can help in the effective communication of the spectacular aspects of sustainability and provide an easily understood comparison of freight alternatives. The developed model offers the possibilities of examining not only specific tasks on freight but also more general topics related to freight transport a few examples of which are as follows:
- the effect of payload loss on SPI in the inter-modal chains due to container and truck tare weight;

- the impact of the systematic variation of input parameters on SPI (for example, how the distance of different legs of inter-modal chain change the effectiveness of an alternative);

- a comparison of the currently feasible and not yet feasible alternatives could give a good basis for the strategic planning of the company (for example, to start the operation of scheduled container liner service for relations with a great amount of cargo flow);

- modelling can help with identifying the weak points of a chain.

However, the model can effectively assist all participants (including the governmental level) interested in sustainable transport with effective communication of sustainability principles. The model can also be ideally used for educational purposes. It can be a tool for training experts in transport logistics so that at the beginning of their career, young professionals should become familiar not only with economic interests but also with equally important social and environmental aspects that are necessary for changes in thinking which is an essential element of sustainable development.

\section{References}

Bokor, Z. 2005. Az intermodális logisztikai szolgáltatások helyzete, fejlesztési lehetőségei [State and possibilities of the intermodal logistic services], Logisztika 10(3): 22-64 (in Hungarian).

Brans, J. P.; Vincke, P. 1985. A preference ranking organization method - (The PROMETHEE method for multiple criteria decision-making), Management Science 31(6): 647-656. doi:10.1287/mnsc.31.6.647

Brauers, W. K. M.; Zavadskas, E. K.; Peldschus, F.; Turskis, Z. 2008. Multi-objective decision-making for road design, Transport 23(3): 183-193. doi:10.3846/1648-4142.2008.23.183-193

Burinskiene, M. 2009. New Methodology for Sustainable Development Towards Sustainable Transportation System, Technological and Economic Development of Economy 15(1): 5-9. doi:10.3846/1392-8619.2009.15.5-9

Churchman, C. W.; Ackoff, R. L.; Arnoff, L. E. 1957. Introduction to Operations Research. Wiley, New York. 645 p.

Daly, H. E. 1991. Steady-State Economics: Second Edition with New Essays. Island Press. 318 p.

Definition and Vision of Sustainable Transportation. 2002. The Centre for Sustainable Transportation (CST). Available from Internet: <http://cst.uwinnipeg.ca/documents/Definition_Vision_E.pdf $>$. $4 \mathrm{p}$.

Edwards, W. 1977. How to use multiattribute utility measurement for social decisionmaking, IEEE Transactions on Systems Man and Cybernetics 7(5): 326-340.

Fülöp, J. 2004. Introduction to Decision Making Methods, in Workshop on Biodiversity \& Ecosystem Informatics, 13-15, December 2004. The Evergreen State College. Available from Internet: <http://academic.evergreen.edu/projects/ bdei/documents/decisionmakingmethods.pdf $>.15$ p.

Ginevičius, R.; Podvezko, V.; Bruzgè, Š. 2008. Evaluating the effect of state aid to business by multicriteria methods, Journal of Business Economics and Management 9(3): 167-180. doi:10.3846/1611-1699.2008.9.167-180 
Indicators for the Integration of Environmental Concerns into Transport Policies. 1999. OECD Proceedings: Working Group on the State of the Environment, ENV/EPOC/ SE(98)1/FINAL. 8-11 October 1999, Paris. Available from Internet: <www.fao.org/ag/againfo/programmes/en/lead/ toolbox/Refer/epoc981.pdf $>.71 \mathrm{p}$.

Jakimavičius, M.; Burinskienè, M. 2007. Automobile transport system analysis and ranking in Lithuanian administrative regions, Transport 22(3): 214-220.

Jakimavičius, M.; Burinskienė, M. 2009. Assessment of Vilnius city development scenarios based on transport system modelling and multicriteria analysis, Journal of Civil Engineering and Management 15(4): 361-368. doi:10.3846/1392-3730.2009.15.361-368

Jakimavičius, M.; Burinskiene, M. 2009. A gisgisgis and multicriteria-based analysis and ranking of transportation zones of Vilnius city, Technological and Economic Development of Economy 15(1):39-48. doi:10.3846/1392-8619.2009.15.39-48

Kaklauskas, A.; Zavadskas, E. K.; Šaparauskas, J. 2009. Conceptual modelling of sustainable Vilnius development, Technological and Economic Development of Economy 15(1): 154-177. doi:10.3846/1392-8619.2009.15.154-177

Macek, D.; Měštanová, D. 2009. Multi-criteria evaluation of crash barier systems types, The Baltic Journal of Road and Bridge Engineering 4(3): 108-114. doi:10.3846/1822-427X.2009.4.108-114

Mačiulis, A.; Vasilis Vasiliauskas, A.; Jakubauskas, G. 2009. The impact of transport on the competitiveness of national economy, Transport 24(2): 93-99. doi:10.3846/1648-4142.2009.24.93-99

Maskeliūnaitė, L.; Sivilevičius, H.; Podvezko, V. 2009. Research on the quality of passenger transportation by railway, Transport 24(2): 100-112. doi:10.3846/1648-4142.2009.24.100-112

Morkvènas, R.; Bivainis, J.; Jaržemskis, A. 2008. Assessment of employee's knowledge potential in transport sector, Transport 23(3): 258-265. doi:10.3846/1648-4142.2008.23.258-265

Operationalising Sustainable Transport and Mobility: The System Diagram and Indicators. 2004. SUMMA (SUstainable Mobility, policy Measures and Assessment) Deliverable 3 of Workpackage 2. Final Version 1.1. Available from Internet: $<$ www.tmleuven.be/project/summa/summa-d3.pdf >. 266 p.

Our Common Future. 1987. World Commission on Environment and Development. Oxford University Press, Oxford, England. 416 p.

Paving the Way for EU Enlargement: Indicators of Transport and Environment Integration, TERM 2002. European Environment Agency. Available from Internet: <http:// www.eea.europa.eu/publications/environmental_issue_report_2002_24/at_download/file>. 64 p.

Pearce, D. W.; Warford, J. J. 1993. World Without End: Economics, Environment and Sustainable Development. Oxford University Press Inc. 456 p.

Podvezko, V. 2009. Application of AHP technique, Journal of Business Economics and Management 10(2): 181-189. doi:10.3846/1611-1699.2009.10.181-189

Podvezko, V.; Podviezko, A. 2010. Dependence of multi-criteria evaluation result on choice of preference functions and their parameters, Technological and Economic Development of Economy 16(1): 143-158. doi:10.3846/tede.2010.09

Rigo, N.; Hekkenberg, R.; Ndiaye, A. B.; Hadhazi, D.; Simongati, G.; Hargitai, C. 2007. Performance assessment of intermodal chains, European Journal of Transport and Infrastructure Research 7(4): 283-300.
Rohács, J.; Simongáti, G. 2007. The role of inland waterway navigation in a sustainable transport system, Transport 22(3): 148-153.

Study on Freight Integrators to the Commission of the European Communities. 2003. Zentrum für Logistik und Unternehmensplanung and partners. 2003. Final Report. Service Contract NTU/B2-7040BS07.18491/2002, Berlin.

Susnienè, D.; Jurkauskas, A. 2008. Stakeholder approach in the management of public transport companies, Transport 23(3): 214-220. doi:10.3846/1648-4142.2008.23.214-220

Sustainable Transportation Performance Indicators (STPI) Project: Report on Phase 3. 2002. The Centre for Sustainable Transportation (CST). Available from Internet: <http:// cst.uwinnipeg.ca/documents/STPI\%20Phase\%203\%20report.pdf $>.125 \mathrm{p}$.

Šelih, J.; Kne, A.; Srdić, A.; Žura, M. 2008. Multiple-criteria decision support system in highway infrastructure management, Transport 23(4): 299-305.

doi:10.3846/1648-4142.2008.23.299-305

Towards Sustainable Transportation. 1996. OECD Proceedings: The Vancouver Conference. Vancouver, British Columbia, 24-27 March 1996. Available from Internet: <www.oecd. org/dataoecd/28/54/2396815.pdf>. 183 p.

Transportation in Canada 2002. Transport Canada Annual Reports. Available from Internet: <www.tc.gc.ca/policy/anre/ menu.htm>.

Turskis, Z.; Zavadskas, E. K.; Peldschus, F. 2009. Multi-criteria optimization system for decision making in construction design and management, Inzinerine Ekonomika - Engineering Economics 1: 7-17.

Ulubeyli, S.; Kazaz, A. 2009. A multiple criteria decisionmaking approach to the selection of concrete pumps, Journal of Civil Engineering and Management 15(4): 369-376. doi:10.3846/1392-3730.2009.15.369-376 